and alone. The loss of, and dearth of recruitment of, public health and community medical officers has been a tragic loss to the public service. No less grievous has been the eclipse of the former chief administrative officers of public health departments. These irreparable losses of expertise represent a setback to the expectations of community medicine which will take many years to overcome.-I am, etc.,

Eastbourne

KENNETH VICKERY Community Physician

\section{Contraceptive Services}

SIR,-Anyone reading Dr. M. V. Smith's letter (6 July, p. 46) stating that the Family Planning Association gave "wholehearted support for the decision to impose no age limit on supplies of contraceptives, following appropriate consultations," might be forgiven for believing that this "support" was the result of wide-ranging democratic discussion with F.P.A. clinic doctors who, along with nurses and lay workers, do the actual work. There was no such discussion. In fact, the first that clinic doctors knew about it was a public statement from the F.P.A.'s Executive in February 1973 calling for free contraceptives "irrespective of age." As chairman of a family planning doctors' group I protested at the time to the appropriate doctors' chairman on the F.P.A. Executive. I never had any satisfactory explanation and the F.P.A. continues to give the impression that an unqualified "no age limit" is acceptable to clinic professional staff.

Now that the Department of Health and Social Security and the F.P.A. have gone one step further and given "guidance" to doctors that the pill can be given to under 16s without parental knowledge, it is surely time that it was known that the muchvaunted democracy of the F.P.A. policymaking is a farce. Clinic doctors (who do the work) are only "advisers" in the F.P.A. and have a very small voice on committees $\rightarrow$ a voice that is easily (and often) ignored in such policy making. Luckily our contract still gives us clinical independence.-I am, etc.,

Wisbech, Cambs

Elizabeth Elliott

SIR,-I would like to take up Dr. M. V. Smith (6 July, p. 46) over his description of local health authorities who freely distribute contraceptives without imposing an age limit as "progressive and far-sighted."

"Progressive" they may be, for it is a term of doubtful merit-we all know examples of progress backwards. But "farslighted"? Is it really far-sighted enough not to discourage young people who want sexual experience before marriage? I am aware of no objective research on this matter, but my impressions are that there are many older people who now deeply regret sexual experimentation in their youth; and I am inclined to believe that more stable marriages result between couples who were virgins before marriage. Certainly swapping of sexual partners before marriage often goes on to swapping after as well.

If this is so, surely it is more far-sighted -though much more difficult - to do everything we can to encourage young people to remain chaste and self-controlled rather than to offer them contraceptives without warning.-I am, etc.,

Kennford, Exeter

W. G. BENSON

SIR,-Closure of the debate on the Annual Report of Council under "Family Planning" (A.R.M. 2, para 13) at the Annual Representative Meeting in Hull prevented me from voicing what I feel must have been in the minds of many Representatives at the meeting that it is insufficient for the report to state the doctor's responsibility for the physical and mental care of our patients, however willing or otherwise they may be to participate in an all-embracing advisory service on contraception, without issuing a warning to society at large that the consequences of permissiveness, in the young in particular, could endanger the preservation of the family unit as the basis of all civilized society and run the risk of uncontrollable disease in the future. Either or both of these consequences could imperil survival of a sound social structure and I feel we would be failing in our duty as doctors if we remained silent on so important a matter.

The Times of Friday 12 July reported that a girl of 12 had given birth to a son in West Hill Horpital, Dartford, Kent, and that mother and child were doing well. One is tempted to amend this statement to read that both children were doing well and point out the distressing and worrying background, known to doctors and social workers in innumerable similar cases. A moment's thought would, I think, convince all those concerned with the future welfare of this country that further thought should be given to sex education, the degree of irresponsibility of the young to the jeopardy of their future, and the resulting undoubted acute misery in human relationships, the consequences of which must be the concern of doctors, educationalists, and politicians alike. -I am, etc.,

Maidstone

BERNARD HALFPENNY

\section{“Market Research" on Private Practice}

SIR,-I was approached today by an organization calling itself the Specialist Research Unit asking me to give them an interview. I established that they were in fact a market research organization and I gave the inevitable groan expecting that I was to be queried why $I$ prescribed brand $X$ rather than brand $Y$ and wouldn't it be better if $I$ used new brand $Z$. However, it appeared I was required to give an hour of my time so that my attitudes to private practice could be evaluated. The area manager of the firm would not (or could not) disclose the name of their client.

In view of the present political climate I declined the interview as I believe that the attitudes of the profession at this moment should not be available to souroes which might quite easily use such information to the profession's detriment.

I write to you in order to warn my colleagues that they may unwittingly agree to such an interview without being aware of its nature.-I am, etc.,

Birstall,

M. J. OLDROYD

Batley, York

\section{Democracy in the Health Service}

SIR,-- "Democracy in the Health Service" is the self-assertive title given by the Secretary of State for Social Services in the Labour Government to a paper published recently. ${ }^{1}$ It criticizes the National Health Service Reorganization Act 1973 for being bureaucratic, appointive, and undemocratic in that it "deliberately separates responsibility for managing the Health Service from responsibility for representing the views of the public as the consumer." This, it says, "is to challenge in a fundamental way the essence of democratic control."

The Government's proposals centre primarily on giving greater power to local authority councillors. The paper states that at least half of the nominees of the community health councils to the area health authorities should be local authority councillors and that one-third of the members of regional and area health authorities should be drawn from local government. Furthermore, R.H.A.s are encouraged to attach weight to prior service on C.H.C.s when making appointments to A.H.A.s Despite all this deliberate inbreeding, the document in a moment of supreme naivety states that "all members of health authorities should participate fully and objectively. . . . It will not be their responsibility to represent local authority, staff or Community Health Council interests."

The following points occur to me.

(1) Community health councils would become yet another arena for party political warfare. The prize of membership of a health authority would be up for grabs, local authority nominations to C.H.C.s (half the membership) would be in the patronage of the majority party, and in time even the other half of the membership, made up from voluntary organization nominees and R.H.A. appointees, might develop an increasingly party political complexion. To active party politicians this might seem to be a good thing and indeed they might question whether health and welfare could ever be other than party political issues. Seen from the other side, however, I wonder how many people who are actively working in health and welfare, or giving help in some form, would consider themselves to be active party politicians. It seems a pity that those who do not should be shouldered away.

(2) Party politicians will remain party politicians whatever authority they serve on, otherwise their prospects for re-election by their own party, let alone by the public, would be bleak indeed. Thus all authorities will become increasingly party political and the situation in health will resemble that in education. In the prevailing two-party system some authorities will chop and change their plans according to whichever local government is in power and other authorities will have their plans chopped and changed for them according to whichever national government is in power.

(3) In time the medical and nursing professions will be outnumbered on the various authorities by previous or current local authority councillors and others with party political lovalties. Then the true purpose of Mrs. Castle's paper will have been achieved - the professions will at last be ensnared; they will have the trappings of representation but in practice will be the servants of the ruling political party, who alone, in the 